\title{
FAMILIAL HEPATIC CIRRHOSIS
}

\author{
BY \\ W. J. S. STILL \\ From the Department of Pathology, Roval Victoria Infirmary, Newcastle-upon-Tyne
}

(RECEIVED FOR PUBLICATION FEBRUARY 3, 1955)

Interest has been revived in the aetiology of hepatic fibrosis in infants by the recent communications of Stokes, Berk, Malamut, Drake, Barondess, Bashe, Wolman, Farquhar, Bevan, Drummond, Maycock, Capps and Bennett (1954) and Dible, Hunt, Pugh, Steingold and Wood (1954).

Dible et al. showed that hepatitis can occur during intra-uterine life with fatal results in the neonatal period, or perhaps later in infancy and childhood. Their eight cases formed a homogeneous group, with similar histological appearances in the liver, and included siblings.

Stokes et al. described a female carrier of an icterogenic virus following homologous serum jaundice, who gave birth to a child who subsequently developed hepatic fibrosis and died at 18 months. They also showed that the plasma of known icterogenic carriers was capable of producing hepatitis in healthy volunteers.

This work has thrown some light on hepatic fibrosis in siblings, and it seems likely that the infants described by Dible et al. are only extreme examples, and that many affected infants must survive with some degree of liver damage. However, there is no indication so far as to the cause of this hepatitis; the common virus of infective hepatitis, virus $\mathbf{A}$, does not seem to be involved. The case of Stokes et al. indicates that placental transfer of virus can occur, but the frequency of this is not known.

Some cases of hepatic fibrosis in siblings may be due to $\mathrm{Rh}$ iso-immunization (Drummond and Watkins, 1946; Craig, 1950), but Gerrard (1952) in a follow-up survey of $\mathrm{Rh}$-affected children could find no evidence of permanent liver damage. A few examples are seen in rare familial states such as Lignac-Fanconi's disease and hepato-lenticular degeneration (Wilson's disease), but the liver damage occurring here is only part of the pathological process, although in Wilson's disease it may be of primary importance.

Cases of hepatic disease in siblings where the aetiology is completely unknown have been called 'familial hepatic cirrhosis' (Weber, 1946).

The family described in this communication is one of seven children; two certainly and most probably a third suffered from severe hepatic disease which caused death in all three before the age of 1 year. An amino-aciduria in certain members of the surviving family is also described.

\section{Case Reports}

Case 1. A boy, aged 11 months, was born in December, 1949. He was a normal, full-term baby, was breast fed for two weeks, and then with National dried milk in adequate quantities. No jaundice was seen at, or after birth, and the mother had a normal pregnancy.

The infant was quite well until six days before admission when he began to pass loose, green, offensive stools after every feed. On the day of admission he was found lying in his cot, with legs and arms twitching: apparently consciousness was not lost. On admission he was

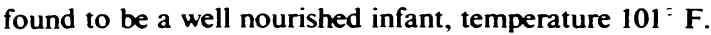
$\left(38 \cdot 3^{-}\right.$C.), having continuous generalized convulsions and emitting an occasional high-pitched cry. Apart from a closed anterior fontanelle, no other physical abnormality was found.

Haemoglobin was $89^{\circ}$ o of normal. A white blood count gave 15,300 (polymorphs 11,500 ). The Wassermann reaction was negative.

No pathogens were found in the stools.

A blood culture was sterile.

A Mantoux test ( 1 in 1,000 O.T.) was negative.

The cerebrospinal fluid contained 15 cells per c.mm. and $300 \mathrm{mg}$. protein.

A radiograph of the skull and chest showed a closed anterior fontanelle, but was otherwise normal.

Bilateral subdural taps revealed no abnormality.

On the assumption that this was an intracranial lesion, the child was transferred to a paediatric unit convenient for a neurosurgeon. Here sedation was gradually withdrawn, and only two further fits were seen until his death. Twitching, mainly left-sided and diaphragmatic, continued and the child was noted to be extremely hypotonic.

Investigation of the cerebrospinal fluid now gave 
17 cells (95\% lymphocytes), $700 \mathrm{mg}$. per $100 \mathrm{ml}$. protein, $102 \mathrm{mg}$. per $100 \mathrm{ml}$. sugar. The fluid was sterile on culture.

Further subdural taps and a ventriculogram showed no abnormality. Post-operatively twitching became more pronounced and the child died the following day.

At necropsy the main findings concerned the liver and lungs. The liver (264 g.) showed gross fatty change throughout, the capsule was smooth, and there was a mild cirrhosis. There were areas of haemorrhage on the pleurae and in the lung substance. The brain and spinal cord were normal.

Histologically the liver showed a moderately advanced multilobular cirrhosis with gross fatty change throughout. The fibrous tissue linking the portal tracts was infiltrated by histiocytes and lymphocytes, being especially abundant where necrosis of liver cells was progressing. Much doubly refractile tissue, mainly surrounding the liver cells, was found. Its nature could not be determined in this case. There was little or no proliferation of bile ducts.

The lung showed extensive interstitial haemorrhage.

The brain and spinal cord showed no abnormality.

Case 2. A boy, aged 12 months, was born in October, 1952, after a normal full-term delivery. No jaundice at, or after, birth was seen. The baby was bottle fed, and was quite well until the age of 4 months, when he began to have mild attacks of diarrhoea and vomiting; occasionally the stools were grey. The vomiting lasted for 48 hours but recurred at about fortnightly intervals.

When first seen in September, 1953, he weighed $16 \mathrm{lb} .8 \mathrm{oz}$. and was not obviously ill. He was now passing four or five green-yellow stools daily. Physical examination was negative, but a rectal swab grew Bact. coli O 111. Treatment with sulphamezathine lessened the frequency of the stools and the baby was discharged.

When he was admitted one month later, he was passing one hard grey stool daily, was vomiting after each feed, and was reluctant to feed at all.

He was a well nourished child, drowsy and extremely hypotonic, although all reflexes were brisk. Fine twitching of the hands, feet, and face were noted. The liver was just palpable, but no jaundice was seen. The temperature was $100 \cdot 8^{\prime} \mathrm{F}$.

The alkali reserve was $46.6 \mathrm{vol}$., the blood urea $24 \mathrm{mg}$. per $100 \mathrm{ml}$., plasma chlorides $592 \mathrm{mg}$. per $100 \mathrm{ml}$., serum calcium $10 \mathrm{mg}$. per $100 \mathrm{ml}$., serum potassium $17.8 \mathrm{mg}$. per $100 \mathrm{ml}$., serum proteins $6.3 \mathrm{~g}$. per $100 \mathrm{ml}$. A blood culture was sterile.

The cerebrospinal fluid contained 4 cells per c.mm., $140 \mathrm{mg}$. protein, $685 \mathrm{mg}$. chlorides, $80 \mathrm{mg}$. sugar, $30 \mathrm{mg}$. urea per $100 \mathrm{ml}$. Culture was sterile.

A Mantoux test ( 1 in 1,000 O.T.) was negative.

An air encephalogram showed no abnormality.

The infant was treated with intravenous glucosesaline and aureomycin. Despite a slight initial favourable response the twitching recurred and became more severe. There was little change in biochemistry and the cerebrospinal protein remained high. Gradually he became more drowsy and apparently blind. He died 38 days after admission.

At necropsy the liver weighed $284 \mathrm{~g}$. and was tawnyyellow, with a well marked granular cirrhosis. A few larger hyperplastic nodules of tissue were present in the

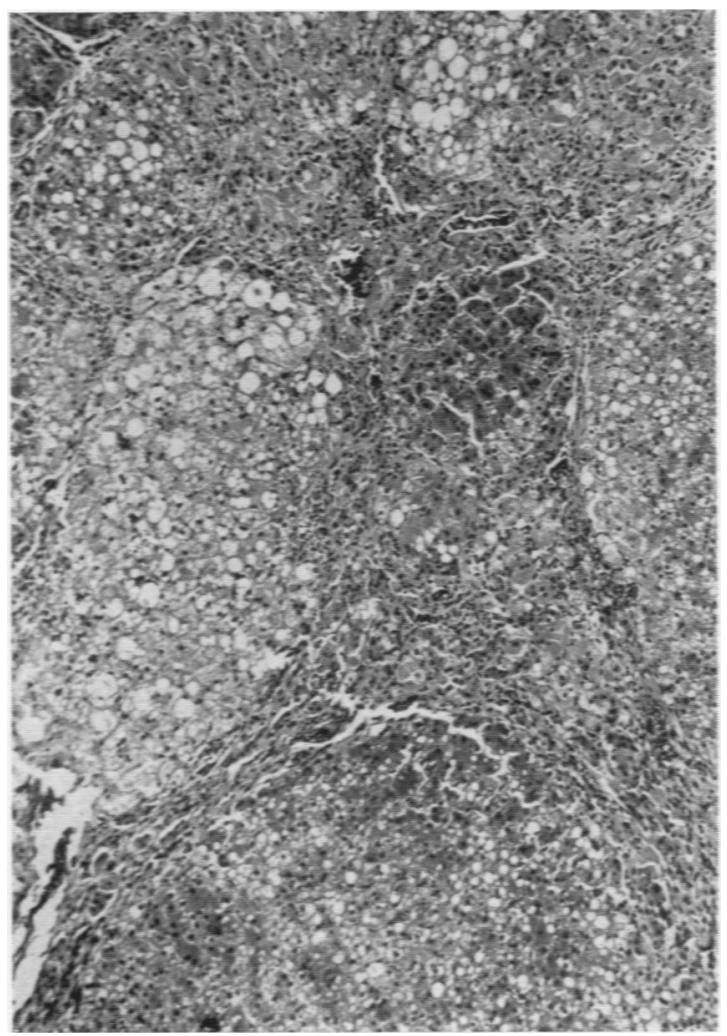

FIG. 1.-Advanced cirrhosis with heavy round cell infiltration of the fibrous tissue bands $(H$. and $E . \times 120)$.

inner surface. No obstruction to the common duct was seen.

No abnormality was found in the brain, spinal cord, or spleen.

Histologically the liver showed an advanced multilobular cirrhosis (Fig. 1) with gross fatty change in all areas (Fig. 2). There were no apparent normal lobules seen and many of the hyperplastic nodules showed central necrosis and vacuolation. The fibrous tissue bands were heavily infiltrated with histiocytes and round cells, indicating that fibrosis was progressive. There was no conspicuous proliferation of bile ducts. Much doubly refractile tissue was seen by polarized light in frozen sections; much of this was considered to be naturally occurring (Duguid and Mills, 1928). However, some basophilic material, principally between the liver cells, was doubly refractile and appeared pathological, 
and seemed to be a fully saturated lipid of the lecithincephalin type (Pearse, personal communication). Its presence, even in such quantities, in the liver is of doubtful significance. No abnormal deposition of iron was present.

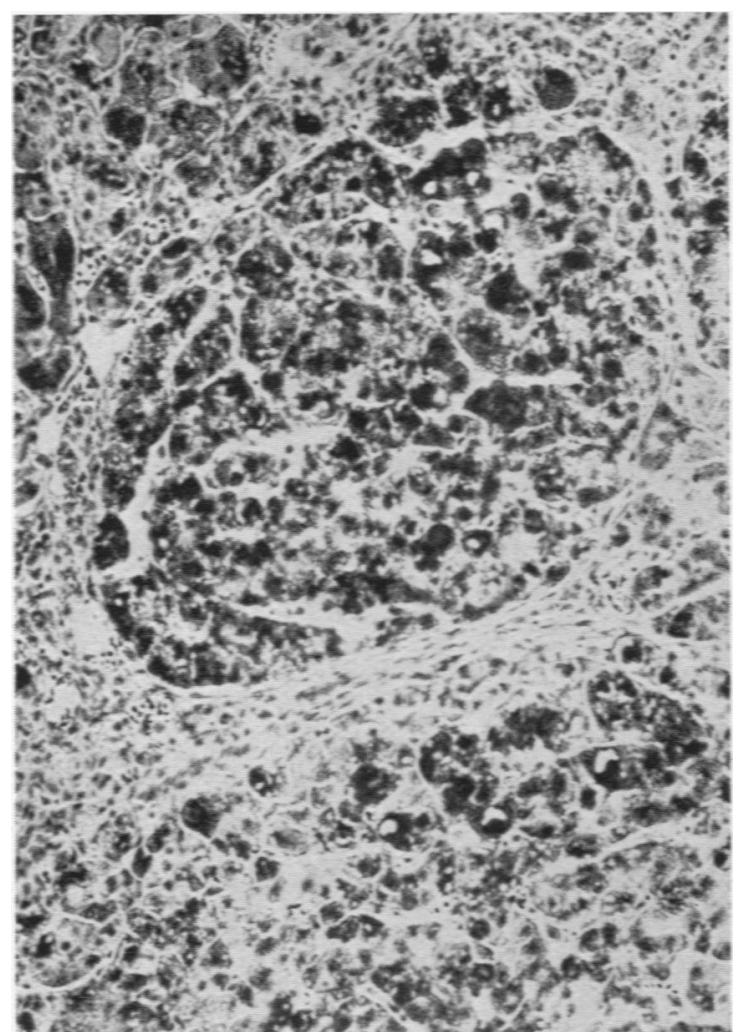

FKG. 2.-A small atypical lobule is shown with gross fatty change in all the cells (fat is shown as black). (Haematoxylin and eosin and Sudan IV $\times$ 240.)

Case 3. A boy, aged 12 months, was born in June, 1940. He appeared a normal child, with no jaundice at or after birth. He was bottle fed on Cow and Gate milk. For some two weeks before death, he was fretful with an occasional loose stool. Two days before death. twitching of legs and arms was noted; the child was quite silent now and limp. He began to vomit and to refuse food; the twitching became generalized next day and was followed by repeated convulsions which lasted until death. The family doctor noted moderate jaundiceapparently as a terminal event. The child was not admitted to hospital and no investigations were made.

These infants present a striking clinical picture and the findings at necropsy in two are similar, indicating that the same process was involved in all three. Apart from the liver disease, the only significant finding, the high C.S.F. protein level, remains unexplained. The histological appearances of the brain and spinal cord in two cases were normal.

The parents and one boy and three girls survive. The parents deny consanguinity. The medical histories and physical examinations in all except the boy were negative. In particular, no history of jaundice was obtained, and the mother had never been transfused.

The surviving boy, aged 6 years, was thin, pale and undersized, and addicted to bouts of vomiting, but with a healthy appetite. The only physical finding of note was a palpable liver edge.

Routine liver function tests and stool examinations were carried out and the results are tabulated (Table 1).

In addition, all Wassermann reactions and titres for leptospira were negative. Both parents were $\mathrm{Rh}$ positive to anti D. All the children were radiographed, but no bony changes were found. Kayser-Fleischer rings were absent.

From the tables it will be seen that all members of the family have a slightly raised serum bilirubin level, a constant finding on numerous occasions. Two of the girls have an excess of urobilinogen and the boy has a raised alkaline phosphatase. The increased flocculations in all, with normal thymol turbidity readings, is unusual.

A more detailed examination of the urines was made by the cyanide-nitroprusside test for cystine (Brand, Harris and Biloon, 1930) and by two-way partition chromatography (Consden, Gordon and Martin, 1944). These examinations were repeated at monthly intervals and tested for any constancy of pattern. The results are given in Table 2.

The amino-acids, which were in excess of normal in all three, apart from cystine, were glycine, aspartic acid, alanine, taurine, $\beta$ isoaminobutyric acid and lysine. The father showed an excess of glutamine also. These patterns are difficult to interpret, but, combined with a positive cyanide-nitroprusside reaction for cystine, it

TABLE 1

LABORATORY INVESTIGATIONS IN THE FAMILY

\begin{tabular}{|c|c|c|c|c|c|c|c|c|c|c|c|}
\hline \multirow{2}{*}{\multicolumn{2}{|c|}{$\begin{array}{l}\text { Member of } \\
\text { Family }\end{array}$}} & \multirow{2}{*}{ Age } & \multicolumn{3}{|c|}{ Urine } & \multirow{2}{*}{$\begin{array}{c}\text { Alkaline- } \\
\text { phospha- } \\
\text { tase (K/A } \\
\text { units) }\end{array}$} & \multirow{2}{*}{$\begin{array}{l}\text { Thymol } \\
\text { Turbidity }\end{array}$} & \multirow{2}{*}{$\begin{array}{c}\text { Thymol } \\
\text { Floccula- } \\
\text { tion } \\
\text { Test }\end{array}$} & \multirow{2}{*}{$\begin{array}{c}\text { Total } \\
\text { Serum } \\
\text { Bilirubin } \\
\text { (mg.) }\end{array}$} & \multirow{2}{*}{$\begin{array}{c}\text { Serum } \\
\text { Inorganic } \\
\text { Phosphorus } \\
\text { (mg.) }\end{array}$} & \multirow{2}{*}{$\begin{array}{l}\text { Stool } \\
\text { Pathogens } \\
\text { Including } \\
\text { Bact. coli }\end{array}$} \\
\hline & & & Albumin & Sugar & $\underset{\text { bilinogen }}{\text { Uro- }}$ & & & & & & \\
\hline $\begin{array}{l}\text { Mother } \\
\text { Father } \\
\text { Girl . . } \\
\text { Boy . . } \\
\text { Girl . . } \\
\text { Girl . . }\end{array}$ & $\begin{array}{l}\cdots \\
\cdots \\
\cdots \\
\cdots \\
\cdots\end{array}$ & $\begin{array}{c}33 \text { years } \\
35 ", \\
7 \% " \\
6 \% " \\
3 \\
3 \text { months }\end{array}$ & $\begin{array}{c}\text { Trace } \\
\text { Nil } \\
\text { Nil } \\
\text { Nil } \\
\text { Nil } \\
\text { Nil }\end{array}$ & $\begin{array}{l}\text { Nil } \\
\text { Nil } \\
\text { Nil } \\
\text { Nil } \\
\text { Nil } \\
\text { Nil }\end{array}$ & $\begin{array}{l}\text { Nil } \\
\text { Nil } \\
\overline{-} \\
\overline{N i l} \\
\text { Nil }\end{array}$ & $\begin{array}{l}5 \\
13 \\
13 \\
18 \\
14 \\
12\end{array}$ & $\begin{array}{l}3 \\
2 \\
2 \\
4 \\
1 \\
2\end{array}$ & $\begin{array}{l}1- \\
1- \\
1= \\
2= \\
1- \\
1-\end{array}$ & $\begin{array}{l}1 \cdot 3 \\
1 \cdot 4 \\
1 \cdot 4 \\
1 \cdot 5 \\
1 \cdot 0 \\
-\end{array}$ & $\begin{array}{l}2 \cdot 6 \\
-1 \cdot 0 \\
4 \cdot 4 \\
4 \cdot 2 \\
-\end{array}$ & $\begin{array}{l}\text { No pathogens } \\
\text { No pathogens } \\
\text { No pathogens } \\
\text { No pathogens } \\
\text { No pathogens } \\
\text { No pathogens }\end{array}$ \\
\hline
\end{tabular}


seems more likely that they represent a progressive hepatic cirrhosis (Walshe, 1953) rather than a familial amino-aciduria as such. Liver biopsy, obviously desirable, could not be performed, so that no definite answer can be given.

TABLE 2

RESULTS OF PARTITION CHROMATOGRAPHY

\begin{tabular}{|c|c|c|c|}
\hline $\begin{array}{l}\text { Member } \\
\text { of } \\
\text { Family }\end{array}$ & & $\begin{array}{c}\text { Cyanide } \\
\text { Nitroprusside } \\
\text { Test }\end{array}$ & Chromatogram Results \\
\hline Father & $\cdots$ & - & $\begin{array}{l}\text { Well marked, generalized amino- } \\
\text { aciduria, including cystine }\end{array}$ \\
\hline Mother & $\cdots$ & - & $\begin{array}{l}\text { Amino-acids at the upper limit of } \\
\text { normal }\end{array}$ \\
\hline Boy $(6$ years $)$ & $\cdots$ & - & $\begin{array}{l}\text { Well marked, generalized amino- } \\
\text { aciduria, including cystine }\end{array}$ \\
\hline $\begin{array}{r}\text { Girl } \\
\text { (7 years) }\end{array}$ & . & - & $\underset{\text { normal }}{\text { Amino-acids at upper limit of }}$ \\
\hline Girl $(3$ years $)$ & . & - & $\begin{array}{l}\text { Moderate generalized amino-aciduria, } \\
\text { including cystine }\end{array}$ \\
\hline Girl ... & & - & Probably normal pattern \\
\hline
\end{tabular}

Urines of close relatives did not show patterns of this order, although investigation was incomplete. The maternal grandmother was found to suffer from cystinuria as defined by Dent and Rose (1951), as also did a maternal uncle. Present evidence (Dent, Heathcote and Joron, 1954) indicates that cystinuria is a condition separate from other amino-acidurias, which breeds true and never has pathological effects outside the urinary system. Since cystinuria is not a very rare disorder (Lewis, 1932), the occurrence in this family may well be coincidental. The indications were that the hepatic cirrhosis and amino-aciduria were confined to the present family. Because of this a search was made for known liver poisons and substances known to cause aminoaciduria, especially lead (Wilson, Thomson and Dent, 1953), but none were found. There was no evidence of malnutrition and living conditions were reasonable.

\section{Discussion}

It is useful to compare the hepatic disease in these infants with known causes of infantile cirrhosis.

Intra-uterine Hepatitis (Dible et al., 1954; Craig and Landing, 1952). It would be attractive to consign the cases to this group, but there are several objections. The infants were widely separated in age, the eldest by 13 years and the youngest by three years; none was visibly jaundiced except terminally in one child, and no history of jaundice could be obtained in the rest of the family. The histological pictures, although not irreconcilable, show differences. That seen in the hepatitis group is a more or less acute necrosis with giant cell reaction, iron storage and extra-medullary haemopoiesis. The children in the present series show a multilobular cirrhosis, which, even in the earlier lesion (Case 1), shows no evidence of an acute reaction. It corresponds to the multilobular cirrhosis of insidious onset in adults and differs from this only in the gross fatty change in all areas. However, Craig and Landing showed that neonatal hepatitis could advance to a coarse cirrhosis in time and Dible's cases also indicated that cirrhosis would occur with survival. On histological grounds alone the possibility that the children under discussion suffered from neonatal or intra-uterine hepatitis remains. However, the amino-aciduria exhibited by several surviving members of the family could hardly be entirely explained by a non-icteric hepatitis.

Familial Amino-aciduria. A comparison with the familial amino-acidurias is also useful. There is no evidence that Lignac-Fanconi disease is involved. The absence of glycosuria, bone changes and hyperphosphataemia are conclusive.

The most interesting comparison is with hepatolenticular degeneration in which multilobular cirrhosis and an amino-aciduria are invariable; the amino-aciduria can be present with histologically normal liver tissue and it can precede neurological signs (Uzman and Denny-Brown, 1948). In 5\% of cases the patients die with liver fibrosis before neurological disorders become apparent (André, 1946). However, several factors are against labelling the present children as examples of hepato-lenticular degeneration. No evidence of the disease, especially Kayser-Fleischer rings, is seen in the surviving siblings, and amino-aciduria in the father does not conform to the dictum that the disease is confined to one generation alone.

Other States. There is no evidence that a hepatic virus has been transferred placentally in these children and a carrier state lasting 13 years appears unlikely. Similarly, $R \mathbf{h}$ immunization as a cause is excluded by both parents being $\mathrm{Rh}$ positive. There is also no evidence to suggest that the children were suffering from a variant of a known lipoidosis. The lecithin-cephalin in the liver was found in no other organs.

Familial Hepatic Cirrhosis. A review of reports on this group of cases (Weber, 1947; Langmead, 1934; Debré, 1939; Poynton and Wyllie, 1926) shows that they were undoubtedly familial, but the disease was recognized later, in children aged from 5 to 12 years, and usually in the advanced stages of portal hypertension. The cause of death was often ruptured oesophageal varices. The families report- 
ed were not investigated for amino-aciduria or $\mathbf{R h}$ antibodies so that comparison is difficult.

Despite this lack, the term "familial hepatic cirrhosis with amino-aciduria" would appear the most appropriate for the family reported now, as the aetiological factors are so far unknown. Liver biopsy, which would be helpful, may be possible if any signs of liver or neurological disease become apparent.

\section{Summary}

A family is described of which three children died in early life with hepatic disease. Three remaining members, including the father, show a generalized amino-aciduria and two relatives suffer from cystinuria.

The hepatic fibrosis in the family reported here is compared with other known cases of hepatic fibrosis in childhood, and it is concluded that they fit into no known group. The name "familial hepatic cirrhosis with amino-aciduria" is suggested.

My thanks are due to Dr. Christine Cooper and Dr. J. M. Stansfeld for the use of clinical notes, and to Dr.
A. L. Latner for the results on partition chromatography. Much of the investigation was carried out in the Department of Pathology, Dryburn Hospital, Durham, and my thanks are also due to the technical staff there and to the Director, Dr. J. E. Ennis.

\section{REFERENCES}

André, M. J. (1946). Rev. belge Sci. méd.. $17,185$.

Brand, E., Harris, M. M. and Biloon, S. (1930). J. biol. Chem., 86, 315 .

Consden, R., Gordon, A. H. and Martin, A. J. P. (1944). Biochem. J., 38, 224

Craig, J. M. (1950). Arch. Path., Chicago, 49, 665.

C and Landing, B. H. (1952). Ibid., 54, 321.

Debré, R. (1939). Proc. roy. Soc. Med., 32, 1173.

Dent, C. E. and Rose, G. A. (1951). Ouart. J. Med., n.s. 20, 205.

Dent, C. E. and Rose, G. A. (1951). Quart. (1954). M. clin. Invest. 33,1210 .

Dible, J. H., Hunt. W. E., Pugh, V. W., Steingold. L. and Wood, J. H. F. (1954). J. Path. Bact., 67. 195

Drummond, R. J. and Watkins, A. G. (1946). Brit. med. J., 1, 984.

Duguid, J. B. and Milks, J. (1928). J. Path. Bact., 31, 721.

Gerrard, J. (1952). Brit. med. J., 1, 1385.

Langmead. F. (1934). Proc. roy. Soc. Med. 27, 939.

Langmead, F. (1934). Proc. roy. Soc. Med., 27,

Pearse, Everson, A. G. (1954). Personal communication.

Poynton, F. J. and Wyllie, W. G. (1926). Archives of Disease in Childhood, 1, 1.

Stokes, J., Jr., Berk, J. E., Malamut, L. L., Drake, M. E., Barondess, J. A., Bashe. W. J., Wolman. I. J., Farquhar, J. D., Bevan, B., Drummond, R. J. Maycock, W. d A.. Capps, R. B. and Bennett, A. M. (1954). J. Amer. med. Ass.. 154. 1059.

Uzman, L. and Denny-Brown, D. (1948). Amer. J. med. Sii., $215,599$.

Walshe, J. M. (1953). Quart. med. J.. n.s. 22, 483.

Weber, F. Parkes (1946). Rare Diseases and Some Debatable Subjects. p. 112, London.

Wilson, V. K., Thomson, M. L. and Dent, C. E. (1953) Lancet, 2, 66. 